\title{
DIFFERENTIATED PRE-ADIPOCYTES ACT AS A DRIVING FORCE FOR PROSTATE CANCER PROLIFERATION, MIGRATION AND EPITHELIAL-MESENCHYMAL TRANSITION
}

\author{
Hüseyin ABDİK ${ }^{1 *}$, Arya Lal ERKILINÇOĞLU ${ }^{2}$, Fikrettin ŞAHİN ${ }^{2}$ \\ ${ }^{1}$ Department of Molecular Biology and Genetics, Faculty of Engineering and Natural Sciences, İstanbul Sabahattin Zaim \\ University, Istanbul, TURKEY \\ ${ }^{2}$ Department of Genetics and Bioengineering, Faculty of Engineering and Architecture, Yeditepe University, İstanbul, \\ TURKEY
}

\section{Cite this article as:}

Abdik H., Erkılınçoğlu A.L. \& Şahin F. 2022. Differentiated pre-adipocytes act as a driving force for prostate cancer proliferation, migration and epithelial-mesenchymal transition. Trakya Univ J Nat Sci, 23(1): 29-36, DOI: 10.23902/trkjnat.978266

\section{Edited by:}

Enes Taylan

*Corresponding Author:

Hüseyin Abdik

huseyin.asbdik@iu.edu.tr

\section{ORCID iDs of the authors:}

HA. orcid.org/0000-0003-3756-0645

ALE. orcid.org/0000-0003-1231-0252

FŞ. orcid.org/0000-0002-7208-8967

Key words:

Obesity

Pre-adipocyte

Prostate cancer cells

Adipogenesis

Condition media

Tumor microenvironment EMT

\begin{abstract}
Obesity is a popular topic due to both its mortality and morbidity rates and related diseases such as cardiovascular diseases, diabetes and cancer. Cancer development and progression relate to many factors one of which is dysfunctional adipocytes found in the tumor microenvironment. However, underlying molecular mechanisms of the obesity-cancer link have not been fully understood. In the current study, condition media (CM) obtained from differentiated pre-adipocytes was used to set an indirect co-culture system with the prostate cancer cell line. Firstly, adipogenesis of 3T3F44-2A was checked by oil red o staining and expressions of specific genes. CM of differentiated 3T3F44-2A was applied on prostate cancer cells (PC3). Cell viability, migration capacity and related gene expression levels of the cells were evaluated. $20 \% \mathrm{CM}$ increased cell viability after $48 \mathrm{~h}$. The administration also induced proliferation, migration and epithelial-mesenchymal transition (EMT)-related gene expressions. The results presented the roles of adipocytes found in the tumor microenvironment and this could allow new therapeutic developments. As a new perspective to evaluate the obesity-cancer link, our model experiment may also be useful for other cancer types.
\end{abstract}

Özet: Obezite, hem mortalite ve morbidite oranları hem de kardiyovasküler hastalıklar, diyabet ve kanser gibi ilişkili olduğu hastalıklar nedeniyle en popüler konulardan biridir. Kanser gelişimi ve ilerlemesi, tümör mikroçevresinde bulunan işlevsiz adipositler gibi birçok faktörle ilgilidir. Bununla birlikte, obezite-kanser bağlantısının altında yatan moleküler mekanizmalar tam olarak anlaşılamamıştır. Mevcut çalışmada, farklılaştırılmış preadipositlerden elde edilen şartlandırılmış ortam $(\mathrm{CM})$, prostat kanseri hücre hattı ile indirekt bir ortak kültür sistemi kurmak için kullanıldı. İlk olarak, 3T3F44-2A'nın adipogenezi, oil red o boyaması ve spesifik genlerin ifadeleri ile kontrol edildi. Farklılaştırılmış 3T3F44-2A'nın CM'si, prostat kanseri hücrelerine (PC3) uygulandı. Hücre canlılığ1, migrasyon kapasitesi ve hücrelerin ilgili gen ekspresyon seviyeleri değerlendirildi. \%20 CM, 48 saat sonra hücre canlılığını arttırdı. Uygulama ayrıca, proliferasyon, migrasyon ve epithelial-mesenchymal aktarım (EMT) ile ilgili gen ekspresyonlarını indükledi. Sonuçlar, tümör mikroçevresinde bulunan adipositlerin rollerini ortaya koydu ve bu, yeni terapötik gelişmelere 1 ş1k tutabilir. Obezite-kanser bağlantısını değerlendirmek için yeni bir bakış açısı olarak, model deneyimiz diğer kanser türleri için de faydalı olabilir.

\section{Introduction}

Obesity has recently been one of the most important health problem that may have consequences for morbidity and mortality (McMillan et al. 2006). According to the 2016 data of the World Health Organization (OECD/WHO), 39\% of the world's adult population is considered overweight and $13 \%$ is obese (OECD/WHO 2020). Obesity is a risk factor for several diseases such as cardiovascular diseases, diabetes, and cancer (Poirier \& Eckel 2002, McMillan et al. 2006, Renehan et al. 2008, Fuster et al. 2016). 
Deposition of exaggerated adipose tissue due to an imbalance between energy intake and expenditure is responsible for obesity (Pérez-Hernández et al. 2014, Fuster et al. 2016). In recent years, substantial evidence has been found that there is a direct correlation between exaggerated adipose tissue and cancer progression (Eheman et al. 2012). Adipose tissue mainly consists of fat storage cells called adipocytes which secrete adipokines such as growth factors, cytokines, chemokines and hormones (Deng \& Scherer 2010, Dumas \& Brisson 2021). These adipokines have a crucial role in tumor growth, migration and invasion due to their paracrine signaling function. This feature of adipokines can alter tumor microenvironment which has a prominent role in carcinogenesis and includes several cell types such as adipocytes, immune cells, endothelial cells, fibroblasts and cancer-associated fibroblasts (Nieman et al. 2011, Toren et al. 2013, Augsten 2014, Park et al. 2014, Pérez-Hernández et al. 2014, Lengyel et al. 2018, Zhang \& Scherer 2018, Quail \& Dannenberg 2019).

Prostate cancer is the second most common cancer type among men worldwide with estimated 1,414,259 newly diagnosed cases in 2020 (GLOBOCAN 2020: New Global Cancer Data|UICC n.d.). Adipose tissue surrounds the prostate tissue and may lead to prostate cancer development (Price et al. 2012). According to epidemiological studies, the accumulation of adipose tissue is associated with prostate cancer aggression, recurrence and mortality (Calle et al. 2003, Freedland et al. 2009, Hu et al. 2014a, b). Additionally, it is known that adipocytes trigger prostate cancer malignancy by inducing epithelial-mesenchymal transition (EMT) (Jung et al. 2013, Su et al. 2019). EMT is a process that cancer cells can undergo during migration, invasion and consequently correlates with high mortality rates (Sherman et al. 2020). Several cellular markers such as Vimentin, Snail, Twist, Slug, MMP's-2,3,9 play roles in EMT (Wallerand et al. 2010). In addition to other genes, Cyclin D and AKT also relate with EMT. Furthermore, EMT is significantly associated with the contribution to the metastatic castration-resistant prostate cancer (mCRPC) progression and metastasis (Matuszak \& Kyprianou 2011).

Previous studies showed that adipose tissue stimulate prostate cancer aggressiveness, through the increased expression of proinflammatory mediators. These mediators induce the activation of JAK/STAT, ERK, and PI3K signaling, thus leading to evasion of apoptosis, stimulating proliferation and invasion of cells (Deep \& Schlaepfer 2016, Neurath \& Finotto 2011, Nguyen \& Tewari 2014, Ribeiro et al. 2012,). Diet-induced obesity has been shown to increase prostate cancer proliferation, invasion, migration, and also matrix metallopeptidase (MMP)-9 activity in a murine model (Price et al. 2012). A wide range of studies have demonstrated that obesity was positively associated with more aggressive PCa, whereas the exact molecular mechanisms that contribute to PCa progression remain unclear. In this study, we aimed to investigate the possible molecular mechanism between obesity and prostate cancer progression in respect to EMT expression of the cells. We used condition medium (CM) as an indirect co-culture model that could mimic the interaction between differentiated 3T3F44-2A pre-adipocytes and prostate cancer cell line (PC3).

\section{Materials and Methods}

\section{Cell Culture and Differentiation}

The pre-adipocyte cells 3T3F44-2A (EF3002; Kerafast) and PC3 cells were cultured in Dulbecco's Modified Eagle Medium with 4.5 g/L D-glucose (DMEM, Invitrogen, Gibco, UK) containing $10 \%$ fetal bovine serum (FBS, Invitrogen, Gibco, UK) and $1 \%$ of penicillin/streptomycin/amphotericin (PSA, Invitrogen, Gibco, UK) (also called as DMEM high complete media) and incubated in a $5 \% \mathrm{CO}_{2}$ humidified incubator. The preadipocyte cells were seeded into T-25 cell culture flask at a concentration of $1.5 \times 10^{5}$ cells/flask. They were cultured in DMEM high complete media and incubated in a $5 \%$ $\mathrm{CO}_{2}$ humidified incubator for post-confluence. Adipogenic induction medium [DMEM high complete media containing $0.25 \mu \mathrm{mol} / \mathrm{L}$ dexamethasone, 0.5 $\mathrm{mmol} / \mathrm{L}$ isobutylmethylxanthine (ibmx) and $1 \mu \mathrm{mol} / \mathrm{L}$ insulin] were added onto the cells to start differentiation. After 2 days, the medium was changed with a new DMEM high complete media and $1 \mu \mathrm{mol} / \mathrm{L}$ insulin. Then the medium was changed with only DMEM high complete media every day up to day 10 .

\section{Collection and Controlling Differentiation}

The medium was collected three times between days 6-10 of differentiation for obtaining CM, filtered through $0.22 \mathrm{~nm}$ filter and stored at $-20^{\circ} \mathrm{C}$. After the differentiation period, the cells were fixed with $4 \%$ PFX and oil red o staining (\#1391, Sigma-Aldrich, Darmstadt, Germany) was performed to detect lipid droplets according to the manufacturer's instructions. The cells were collected to isolate total mRNA and qPCR analysis were done with adipogenesis-specific marker genes to check differentiation.

\section{Cell Viability Assay (MTS)}

MTS assay (3-(4,5-di-methyl-thiazol-2-yl)-5-(3carboxy-methoxyphenyl)-2-(4-sulfo-phenyl)-2Htetrazolium) (\#G3582, CellTiter96 AqueousOne Solution; Promega, Southampton, UK) was performed to evaluate the effects of different concentrations of $\mathrm{CM}$ on the cell viability of the PC 3 cells. The cells were seeded onto 96 -well plates at a concentration of $5 \times 10^{3}$ cells/well. The next day, five different concentrations of the CM (10\% to $50 \%$, with $10 \%$ intervals) were administered onto the cells. The assay was performed at 24, 48 and 72 hours after administration and colorimetric changes in the wells were measured by ELISA microplate reader (Biotek, Winooski, VT) at $495 \mathrm{~nm}$. 
Annexin V\& Dead Cell Assay

Apoptosis was assessed by the Muse ${ }^{\circledR}$ Annexin V \& Dead Cell Kit (Merck Millipore, USA and Canada). PC3 cells were seeded onto 6-well plates at a concentration of $1.5 \times 10^{5}$ cells/well. The next after, $20 \% \mathrm{CM}$ which was decided according to MTS results was applied onto the cells. 48 hours later, the cells were collected and Annexin $\mathrm{V}$ assay was performed according to the manufacturer's instructions and Muse ${ }^{\circledR}$ Cell Analyser was used to analyse.

\section{Cell Cycle Assay}

Cell cycle position was determined by Muse ${ }^{\circledR}$ Cell Cycle Kit (Merck Millipore USA and Canada). PC3 cells were seeded onto 6 -well plates $\left(1.5 \times 10^{5}\right.$ cells/well). The next day, 20\% CM was applied onto the cells. 48 hours later, the cells were collected and fixed in $70 \%$ ethanol at $-20^{\circ} \mathrm{C}$ for 2 hours. Cell Cycle reagent was used according to the manufacturer's instructions and Muse $^{\circledR}$ Cell Analyser was used for the analysis.

\section{Quantative Polimerase Chain Reaction ( $q P C R$ )}

The expressions of adipogenesis-related genes such as CEBP $\alpha$, FABP4, GLUT4, and PPAR $\gamma$ in differentiated 3T3F44-2A were evaluated. The expression levels of proliferation and EMT-related genes in PC3 cells under the $20 \% \mathrm{CM}$ administration were also determined. The cells were seeded onto 6 -well plates $\left(1.5 \times 10^{5}\right.$ cells/well). The next day, 20\% CM was applied onto the cells. 48 hours later, the cells were collected and RNA isolation was performed by using High Pure RNA Isolation Kit (Roche) according to the manufacturer's instructions. Isolated total RNA was used for cDNA synthesis by Transcriptor High Fidelity cDNA Synthesis Kit (Roche) according to the manufacturer's instructions. SYBR Green mix (Applied Biosystems, UK), specific primers for AKT, CYCLIN-D1, MMP-9, NFאB, P38 MAPK, SNAIL-1, TWIST, and VIMENTIN and synthesized cDNA were mixed for qPCR reaction by running iCycler RT-PCR system (CFX Real Time System; Bio-Rad, Singapore).

\section{Western Blot Analysis}

Proliferation and EMT-related protein expression levels of the PC3 cells under the 20\% CM administration were evaluated by western blot analysis. The cells were seeded onto 6-well plates $\left(1.5 \times 10^{5}\right.$ cells/well $)$. The next day, $20 \% \mathrm{CM}$ was applied onto the cells. 48 hours later, the cells were collected and protein isolation was performed. RIPA buffer with protease inhibitor cocktail, PMSF and sodium orthovanadate (Santa Cruz Biotechnology, USA) were used for protein isolation. The concentrations of the isolated proteins were measured by Bicinchoninic acid Assay (BCA) (Thermo Scientific ${ }^{\mathrm{TM}}$, Waltham, MA USA). The proteins were electrophoresed in Any $\mathrm{kD}^{\mathrm{TM}}$ Mini15 PROTEAN ${ }^{\circledR}$ TGX Stain-Free ${ }^{\mathrm{TM}}$ precast gels (Bio-Rad, USA). After electrophoresis, the proteins were transferred from gel to nitrocellulose membrane and incubated primary antibodies p-Akt (\#4060 Cell Signaling Technology), Akt (\#9272, Cell Signalling Technology, USA), NFкB(\#8242; Cell
Signaling Technology), (Snail (\#3895 Cell Signaling Technology), Vimentin (\#5741 Cell Signaling Technology) and Gapdh (\#5174 Cell Signaling Technology) for overnight at $4^{\circ} \mathrm{C}$. The next day, the membranes were washed and treated with secondary antibodies (anti-rabbit, \#7074 Cell Signaling Technology) for 1 hour at room temperature (RT). The bands were photographed ChemiDoc MP imaging system (Bio-Rad, USA) and the band intensities were calculated by Image Lab software program.

\section{Scratch Assay}

To evaluate the migration capacities of PC3 cells under 20\% CM administration, the cells were seeded onto 6 -well plates at a concentration of $1.5 \times 10^{5}$ cells/well. The next day, scratch model was formed with the help of a sterile pipette and $20 \% \mathrm{CM}$ was applied. At 0 and 24 hours, each well was photographed at three randomly selected areas using the Zeiss PrimoVert light microscope with an AxioCam ERc5s camera (Carl Zeiss Microscopy, LLC, Thornwood, NY, USA) and the closure area rate were calculated.

\section{Statistical Analysis}

One-way analysis of variance (ANOVA) followed by Tukey's post hoc test was used for statistical analysis. Differences with $\mathrm{p}$ values less than 0.05 were considered statistically significant.

\section{$\underline{\text { Abbreviation List }}$}

BCA Bicinchoninic Acid Assay

CM Condition Media

EMT Epithelial-mesenchymal Transition

mCRPC Metastatic Castration-resistant Prostate Cancer

WHO World Health Organization

FBS Fetal Bovine Serum

PSA Penicillin/Streptomycin/Amphotericin

qPCR Quantative Polimerase Chain Reaction

ANOVA Analysis of Variance

DMEM Dulbecco's Modified Eagle Medium

\section{Results}

Pre-adipocytes were successfully differentiated into mature adipose cells and CM were collected

$\mathrm{CM}$ of the differentiated pre-adipocyte were collected between days 6-10 of differentiation. To check the differentiation, lipid droplets where localized in the differentiated cells were detected with oil red o staining. While the control group (undifferentiated group) was not stained with oil red o, differentiated group was profusely stained (Fig. 1a). Besides, expressions of the adipogenesis-related genes such as CEBP $\alpha$, FABP4, GLUT4 and PPAR $\gamma$ were significantly overexpressed in the differentiated group compared to undifferentiated preadipocytes (Fig. 1b). 
While the selected dose of $C M$, which increased the cell viability of the PC3 cells, did not display apoptotic activity, it caused accumulation of the cells in G2/M phase.

To decide non-toxic concentration of the CM for further experiments, MTS assay was done. While other doses did not display any significant effect on the cell viability of PC3 cells, 20\% CM administration significantly increased the cell viability of the cells at 48 and 72 hours. In order to assess the non-toxic effect of $20 \%$ CM on PC3 cells, Annexin V/PI assay was carried out. Similar apoptotic rates were detected in control ( $\sim 6.55 \%)$ and 20\% CM ( 7.25\%) groups. Moreover, cell cycle distribution of the PC3 cells under $20 \%$ CM administration were detected with cell cycle analysis. The percentage of the cells in G0/G1 phase was significantly decreased in $20 \% \mathrm{CM}$ group $(\sim 42.7 \%)$ compared to the control group ( $48.1 \%)$, while percentages of the cells in $\mathrm{S}$ phase were similar in both groups. The most dramatic change was detected in $\mathrm{G} 2 / \mathrm{M}$ phase. $20 \% \mathrm{CM}$ caused accumulation of the PC3 cells in G2/M phase at a percentage of $\sim 34.4 \%$ while in the control group, this ratio was $\sim 27.0 \%$.

a

Control

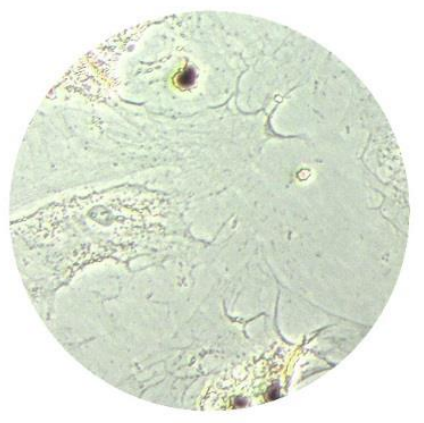

b
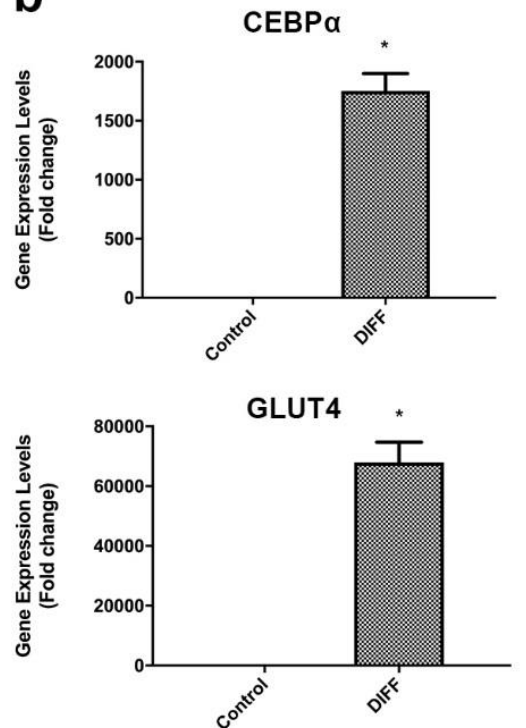

The proliferation and EMT-related markers were significantly upregulated with $20 \%$ CM administration

Proliferation and EMT-related gene expressions analyses were performed with qPCR. Firstly, expression of proliferation related genes such as AKT, CYCLIN-D1, NF$\kappa \mathrm{B}$ and P38-MAPK were evaluated in $48 \mathrm{~h}$. $20 \% \mathrm{CM}$ significantly increased AKT, CYCLIN-D1, NF- $\kappa$ B and P38-MAPK by $2.64 \pm 0.43,2.62 \pm 0.48,1.83 \pm 0.20$ and $1.95 \pm 0.38$ folds, respectively. EMT-related genes including SNAIL-1, MMP-9, TWIST and VIMENTIN were also determined after $20 \% \mathrm{CM}$ administration. The applied dose of CM caused significantly overexpression in SNAIL-1 (1.67 \pm 0.41$)$, MMP-9 $(1.95 \pm 0.33)$, TWIST $(2.59 \pm 0.35)$ and VIMENTIN $(3.91 \pm 0.5)$. Moreover, the effects of $20 \% \mathrm{CM}$ on proliferation and EMT-related protein expression levels were detected in western blot analysis. While 20\% CM did not affect AKT, the expression level of p-AKT, active form of AKT, was significantly overexpressed by $1.70 \pm 0.06$ fold. NF- $\mathrm{KB}$ and SNAIL-1 levels were significantly upregulated by $1.51 \pm 0.04$ and 1.58 \pm 0.05 folds, respectively, but VIMENTIN level $(1.03 \pm$ 0.07 ) was not changed compared to the control group.
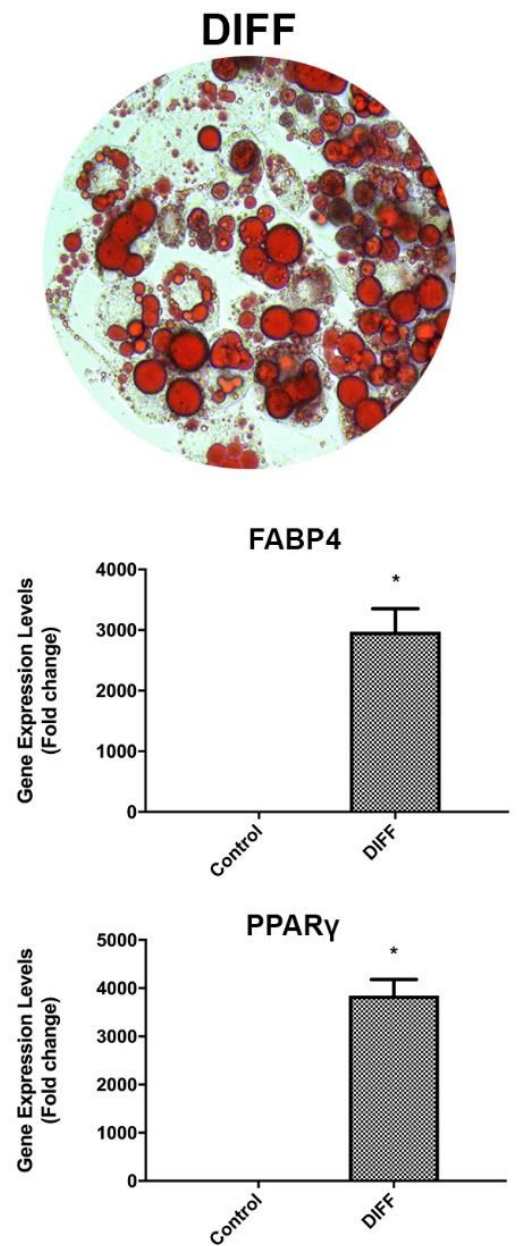

Fig. 1. a. Representative images of oil red o stained undifferentiated (control) and differentiated preadipocytes (DIFF), b. the expression levels of adipogenic marker genes, CEBP $\alpha$, FABP4, GLUT4, and PPAR $\gamma$. ${ }^{*} \mathrm{p}<0.05$. 


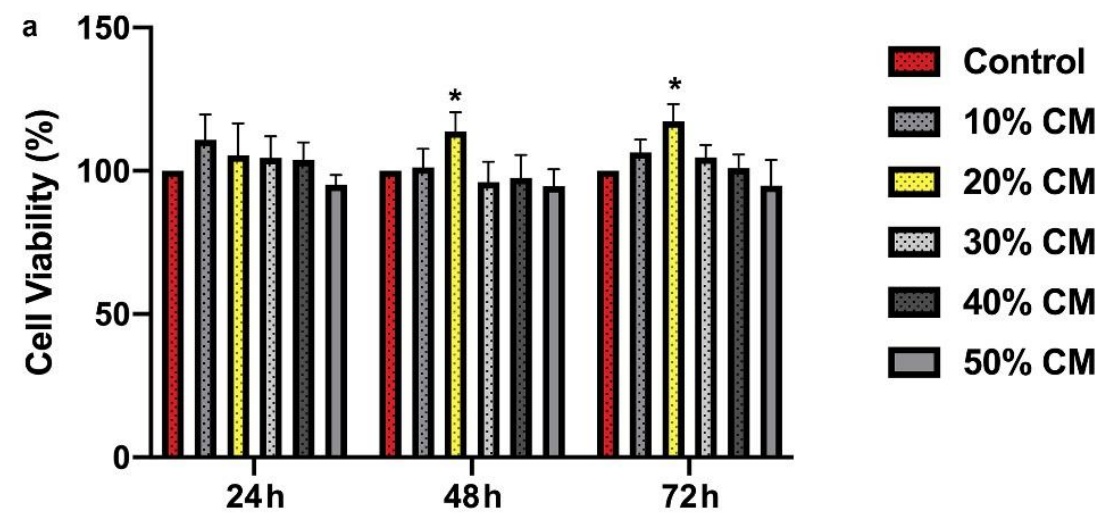

b
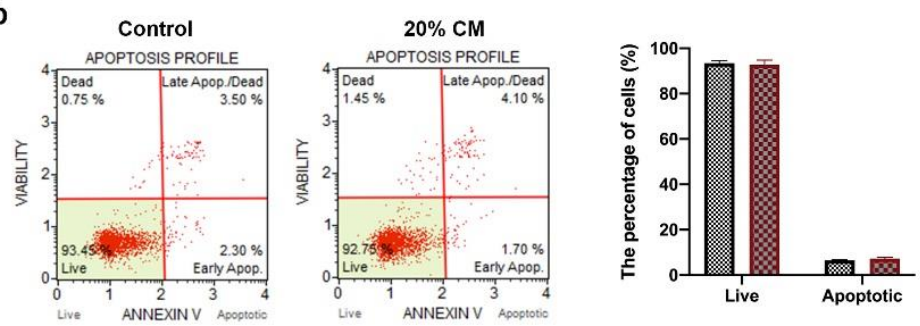

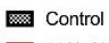

이 $20 \% \mathrm{CM}$
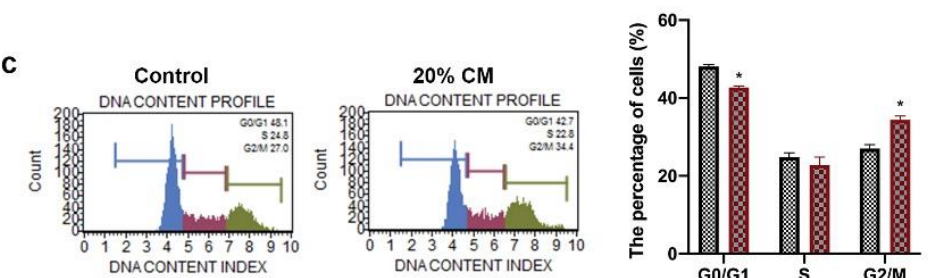

Control

$20 \% \mathrm{CM}$

Fig. 2. a. The effects of different concentrations of CM (10-50\%) on cell viability of PC3 cells for 24,48 and 72 h, b. Annexin V-PI apoptosis analysis results of 20\% CM treated and untreated (Control) PC3 cells for $48 \mathrm{~h}$. Bar graph indicates the percentages of viable and apoptotic cells, c. cell cycle distribution of the 20\% CM treated and untreated (Control) PC 3 cells for 48 h. Bar graph indicates the percentages of the cell cycle distribution. *p<0.05. CM: Conditioned Medium.

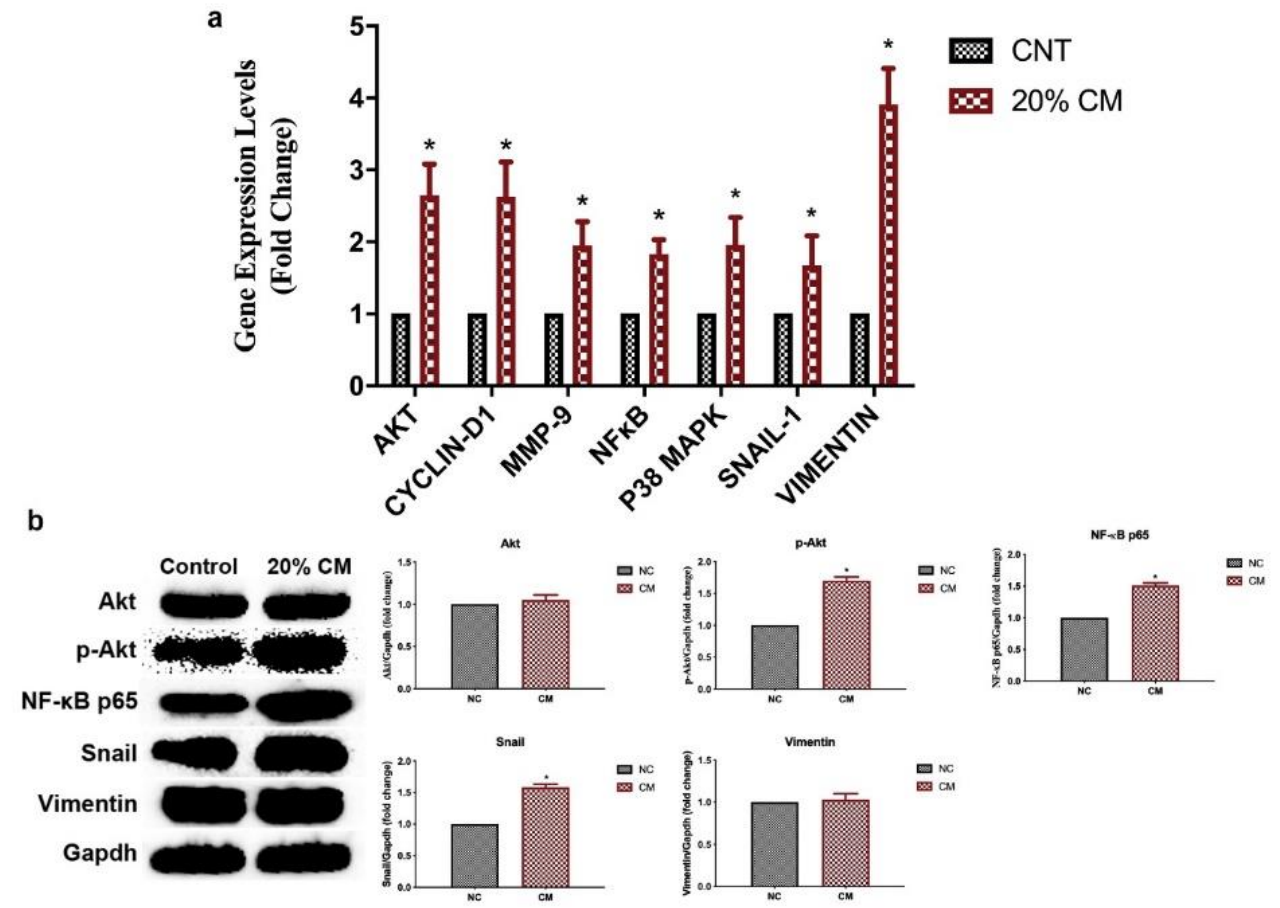

Fig. 3. Related expression levels of $20 \% \mathrm{CM}$ treated and untreated (Control) PC 3 cells for $48 \mathrm{~h}$, a. gene, b. protein. ${ }^{*} \mathrm{p}<0.05$. CM: Conditioned Medium. 

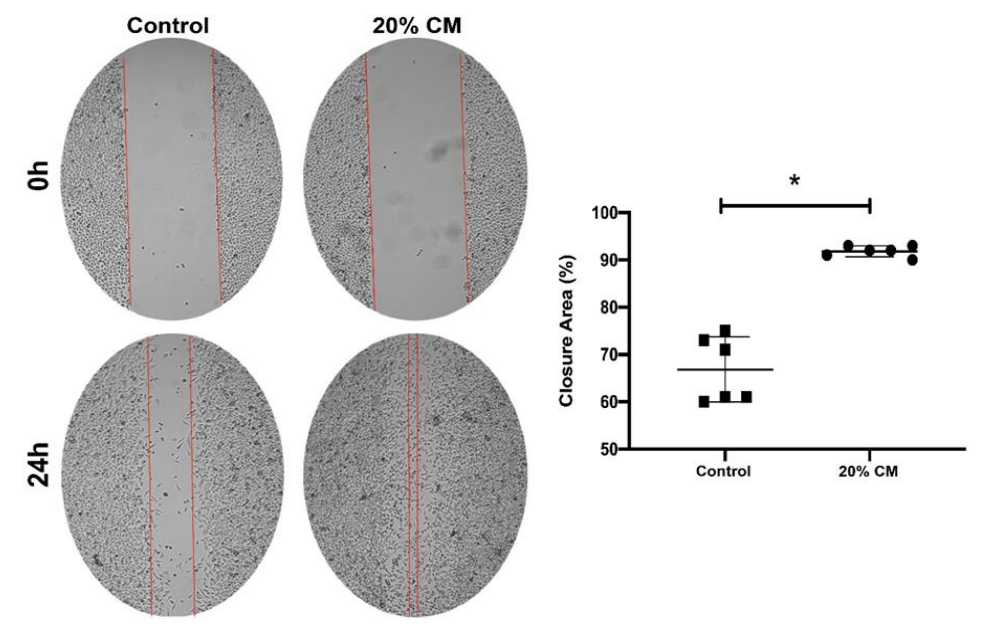

Fig. 4. Scratch assay photographs of $20 \% \mathrm{CM}$ treated and untreated (Control) PC 3 cells at 0 and $24 \mathrm{~h}$. Bar graph indicates the percentage of wound closure. * $\mathrm{p}<0.05$. CM: Conditioned Medium.

$20 \%$ CM contributed to migration of PC3 cells in scratch assay

To detect the effects of $20 \% \mathrm{CM}$ on the migration capacities of the PC3 cells, scratch assay was carried out. Each well was photographed at $0 \mathrm{~h}$ and $24 \mathrm{~h}$ and the closure area rate was calculated. The results indicated that $20 \% \mathrm{CM}$ significantly enhanced migration capacities of the PC3 cells compared to the control group. 20\% CM administration caused $91.83 \% \pm 1.16$ closure rate, while $66.83 \% \pm 6.88$ closure area rate was calculated in the control group.

\section{Discussion}

Over 1.9 billion adults were overweight and more than 650 million of these were obese in 2016, based on WHO data (OECD/WHO, 2020). The high population rate of obese patients requires a good comprehension of associated diseases and treatments since obesity brings along multiple metabolic and cardiovascular diseases, endocrine problems and cancer progression (Bray 2002, Eckel et al. 2005, Tumminia et al. 2019, Zalesin et al. 2008). Several studies suggest that obesity promotes prostate cancer aggressiveness and incidence $(\mathrm{Hu}$ et al. 2014a, Su et al. 2019). However, the possible molecular mechanism of obesity-associated prostate cancer progression and metastasis still remains blurry and needs to be elucidated.

This study aims to demonstrate the effect of differentiated pre-adipocytes on metastatic castrationresistant prostate cancer proliferation and migration via indirect co-culture by using CM from differentiated preadipocytes. The indirect co-culture model was successfully used to reveal obesity-breast cancer cells of different p53 statuses (Abdik 2021). CM was collected in the adipocyte maturation phase (days 6-10). According to the previous studies, CM includes several extracellular vesicles, growth factors, cytokines and could promote cancer cell proliferation and migration (Dowling \& Clynes 2011, Ko et al. 2019). These secretory adipokines of differentiated preadipocytes can induce EMT which is a critical process in transforming tumor cells into aggressive cells (Lee et al. 2015, Su et al. 2019).

In the present study, $20 \% \mathrm{CM}$ of differentiated preadipocytes increased the cell viability of PC3 without displaying significant apoptotic cell death in other treatment groups. Moreover, most of the PC3 prostate cancer cells accumulated in $\mathrm{G} 2 / \mathrm{M}$ phase. In gene expression analysis, CM increased expressions of the proliferation-related genes AKT, CYCLIN-D1, NF- $\kappa$ B and P38-MAPK in PC3 cell line. Proliferation-related protein upregulations of $\mathrm{p}-\mathrm{AKT}$ and $\mathrm{NF}-\mathrm{\kappa B}$ were also upregulated. This increase of cell viability can associate with the low prognosis of the prostate cancer in overweight patients.

Recent studies have demonstrated that adipocytes can trigger cancer cell proliferation, migration, and metastasis by inducing EMT (Lee et al. 2015, Su et al. 2019). Dysfunctional adipocytes enhance the malignancy of prostate cancer by inducing EMT (Jung et al. 2013, Su et al. 2019). In the present study, the relation between obesity-associated EMT and prostate cancer progression was proven by scratch assay, qPCR and Western blotting. Our findings indicated that $20 \% \mathrm{CM}$ administration caused upregulation of EMT markers, SNAIL-1, MMP-9 and TWIST. Riberio et al. (2012) reported that periprostatic adipose tissue $\mathrm{CM}$ enhances prostate cancer proliferation through increased MMPs, which has a central role in tumor progression with the association of EMT (Ribeiro et al. 2012). However, as one of the hallmarks of EMT, we did not observe any significant difference of Vimentin expression. In addition, migration capacities of the CM treated PC3 cells were higher than the untreated group. The treated cells closed the gap much faster due to the induction of EMT. Su et al. (2019) have also shown that the co-culture of adipose stromal cells with LNCap and PC3 prostate cancer cell lines enhances the migration of the cells. Moreover, EMT significantly contributes to metastatic castration-resistant prostate cancer (mCRPC) progression and metastasis (Matuszak \& 
Kyprianou 2011). Overall, the up regulation of EMTrelated genes and the scratch assay results indicate the enhanced migratory effect of the prostate cancer cell which can accelerate the spread of the cancer cells to other tissues and organs.

In conclusion, adipocytes, which increased as a result of the progression of obesity has a quiet substitutional role in the progression of prostate cancer and this study suggests that $\mathrm{CM}$ of differentiated pre-adipocytes may promote prostate cancer progression through inducing EMT. Understanding the role of adipocytes on prostate cancer progression could allow new therapeutic developments and increase obese patient survival. As a new approach to determine the obesity-cancer link, our model experiment may also be helpful for other cancer types.

\section{References}

1. Abdik, E.A. 2021. Differentiated pre-adipocytes promote proliferation, migration and epithelial-mesenchymal transition in breast cancer cells of different p53 status. Molecular Biology Reports, 48(6), 5187-5198.

2. Augsten, M. 2014. Cancer-Associated Fibroblasts as Another Polarized Cell Type of the Tumor Microenvironment. In Frontiers in Oncology, 4: 62.

3. Bray, G.A. 2002. The underlying basis for obesity: relationship to cancer. The Journal of Nutrition, 132(11): 3451-3455.

4. Calle, E.E., Rodriguez, C., Walker-Thurmond, K. \& Thun, M.J. 2003. Overweight, Obesity, and Mortality from Cancer in a Prospectively Studied Cohort of U.S. Adults. New England Journal of Medicine, 348(17): 1625-1638. https://doi.org/10.1056/NEJMoa021423

5. Deep, G., \& Schlaepfer, I. R. (2016). Aberrant lipid metabolism promotes prostate cancer: role in cell survival under hypoxia and extracellular vesicles biogenesis. International Journal of Molecular Sciences, 17(7), 1061.

6. Deng, Y. \& Scherer, P.E. 2010. Adipokines as novel biomarkers and regulators of the metabolic syndrome. Annals of the New York Academy of Sciences, 1212(1): E1E19. $\quad$ https://doi.org/https://doi.org/10.1111/j.17496632.2010.05875.x

7. Dowling, P. \& Clynes, M. 2011. Conditioned media from cell lines: A complementary model to clinical specimens for the discovery of disease-specific biomarkers. Proteomics, 11(4): 794-804.

8. Dumas, J.-F. \& Brisson, L. 2021. Interaction between adipose tissue and cancer cells: role for cancer progression. Cancer and Metastasis Reviews, 40(1): 31-46. https://doi.org/10.1007/s10555-020-09934-2

9. Eckel, R.H., Grundy, S.M. \& Zimmet, P.Z. 2005. The metabolic syndrome. The Lancet, 365(9468): 1415-1428.

10. Eheman, C., Henley, S.J., Ballard-Barbash, R., Jacobs, E.J., Schymura, M.J., Noone, A.-M., Pan, L., Anderson, R.N., Fulton, J.E., Kohler, B.A., Jemal, A., Ward, E., Plescia, M., Ries, L.A.G. \& Edwards, B.K. 2012. Annual Report to the Nation on the status of cancer, 1975-2008, featuring cancers associated with excess weight and lack of sufficient
Ethics Committee Approval: Since the article does not contain any studies with human or animal subject, its approval to the ethics committee was not required.

Author Contributions: Concept: H.A., Desing: H.A., Execution: H.A., A.L.E., Material supplying: F.Ş., Data acquisition: H.A., A.L.E., Data analysis/interpretation: H.A., A.L.E., Writing: H.A., A.L.E., Critical review: H.A.

Conflict of Interest: The authors have no conflicts of interest to declare.

Funding: The authors declared that this study has received no financial support.

physical activity. Cancer, 118(9): 2338-2366. https://doi.org/https://doi.org/10.1002/cncr.27514

11. Freedland, S.J., Bañez, L.L., Sun, L.L., Fitzsimons, N.J. \& Moul, J.W. 2009. Obese men have higher-grade and larger tumors: an analysis of the duke prostate center database. Prostate Cancer and Prostatic Diseases, 12(3): 259-263. https://doi.org/10.1038/pcan.2009.11

12. Fuster, J J., Ouchi, N., Gokce, N. \& Walsh, K. 2016. Obesity-Induced Changes in Adipose Tissue Microenvironment and Their Impact on Cardiovascular Disease. Circulation Research, 118(11): 1786-1807. https://doi.org/10.1161/CIRCRESAHA.115.306885

13. Hu, M.-B., Liu, S.-H., Jiang, H.-W., Bai, P.-D. \& Ding, Q. 2014. Obesity affects the biopsy-mediated detection of prostate cancer, particularly high-grade prostate cancer: a dose-response meta-analysis of 29,464 patients. PloS One, 9(9): e106677-e106677. https://doi.org/10.1371/journal.pone.0106677

14. Hu, M.-B., Xu, H., Bai, P.-D., Jiang, H.-W. \& Ding, Q. 2014. Obesity has multifaceted impact on biochemical recurrence of prostate cancer: a dose-response metaanalysis of 36,927 patients. Medical Oncology, 31(2): 829. https://doi.org/10.1007/s12032-013-0829-8

15. Jung, Y., Kim, J.K., Shiozawa, Y., Wang, J., Mishra, A., Joseph, J., Berry, J.E., McGee, S., Lee, E., Sun, H., Wang, J., Jin, T., Zhang, H., Dai, J., Krebsbach, P.H., Keller, E.T., Pienta, K.J. \& Taichman, R.S. 2013. Recruitment of mesenchymal stem cells into prostate tumours promotes metastasis. Nature Communications, 4(1): 1795. https://doi.org/10.1038/ncomms2766

16. Ko, J.-H., Um, J.-Y., Lee, S.-G., Yang, W.M., Sethi, G. \& Ahn, K.S. 2019. Conditioned media from adipocytes promote proliferation, migration, and invasion in melanoma and colorectal cancer cells. Journal of Cellular Physiology, 234(10): 18249-18261.

17. Lee, Y., Jung, W.H. \& Koo, J.S. 2015. Adipocytes can induce epithelial-mesenchymal transition in breast cancer cells. Breast Cancer Research and Treatment, 153(2): 323-335.

18. Lengyel, E., Makowski, L., DiGiovanni, J. \& Kolonin, M.G. 2018. Cancer as a Matter of Fat: The Crosstalk between Adipose Tissue and Tumors. Trends in Cancer, 4(5): 374-384. https://doi.org/10.1016/j.trecan.2018.03.004 
19. Matuszak, E.A. \& Kyprianou, N. 2011. Androgen regulation of epithelial-mesenchymal transition in prostate tumorigenesis. Expert Review of Endocrinology \& Metabolism, 6(3): 469-482. https://doi.org/10.1586/eem.11.32

20. McMillan, D.C., Sattar, N., Lean, M. \& McArdle, C.S. 2006. Obesity and cancer. BMJ, 333(7578): 1109-1111. https://doi.org/10.1136/bmj.39042.565035.BE1

21. Neurath, M. F., \& Finotto, S. (2011). IL-6 signaling in autoimmunity, chronic inflammation and inflammationassociated cancer. Cytokine \& growth factor reviews, 22(2), 83-89.

22. Nguyen, D. P., Li, J., \& Tewari, A. K. (2014). Inflammation and prostate cancer: the role of interleukin 6 (IL-6). BJU international, 113(6), 986-992.

23. Nieman, K.M., Kenny, H.A., Penicka, C.V, Ladanyi, A., Buell-Gutbrod, R., Zillhardt, M.R., Romero, I.L., Carey, M.S., Mills, G.B., Hotamisligil, G.S., Yamada, S.D., Peter, M.E., Gwin, K. \& Lengyel, E. 2011. Adipocytes promote ovarian cancer metastasis and provide energy for rapid tumor growth. Nature Medicine, 17(11): 1498-1503. https://doi.org/10.1038/nm.2492

24. OECD/WHO (2020), "Overweight and obesity", in Health at a Glance: Asia/Pacific 2020: Measuring Progress Towards Universal Health Coverage, OECD Publishing, Paris.

25. Park, J., Morley, T.S., Kim, M., Clegg, D.J. \& Scherer, P.E. 2014. Obesity and cancer--mechanisms underlying tumour progression and recurrence. Nature Reviews. Endocrinology, 10(8): 455-465. https://doi.org/10.1038/nrendo.2014.94

26. Pérez-Hernández, A.I., Catalán, V., Gómez-Ambrosi, J., Rodríguez, A. \& Frühbeck, G. 2014. Mechanisms linking excess adiposity and carcinogenesis promotion. Frontiers in Endocrinology, 5: 65. https://doi.org/10.3389/fendo.2014.00065

27. Poirier, P. \& Eckel, R.H. 2002. Obesity and cardiovascular disease. Current Atherosclerosis Reports, 4(6): 448-453. https://doi.org/10.1007/s11883-002-0049-8

28. Price, R.S., Cavazos, D.A., De Angel, R.E., Hursting, S.D. \& deGraffenried, L.A. 2012. Obesity-related systemic factors promote an invasive phenotype in prostate cancer cells. Prostate Cancer and Prostatic Diseases, 15(2): 135143. https://doi.org/10.1038/pcan.2011.54

29. Ribeiro, R. J., Monteiro, C. P., Cunha, V. F., Azevedo, A. S., Oliveira, M. J., Monteiro, R., Fraga, A.M., Príncipe, P., Lobato, C., Lobo, F., Morais, A., Silva, V., SanchesMagalhães, J., Oliveira, J., Guimarães, J.T., Lopes, C.M.S., \& Medeiros, R. M. (2012). Tumor cell-educated periprostatic adipose tissue acquires an aggressive cancerpromoting secretory profile. Cellular Physiology and Biochemistry, 29(1-2): 233-240.
30. Quail, D.F. \& Dannenberg, A.J. 2019. The obese adipose tissue microenvironment in cancer development and progression. Nature Reviews Endocrinology, 15(3): 139154. https://doi.org/10.1038/s41574-018-0126-X

31. Renehan, A.G., Tyson, M., Egger, M., Heller, R.F. \& Zwahlen, M. 2008. Body-mass index and incidence of cancer: a systematic review and meta-analysis of prospective observational studies. The Lancet, 371(9612): 569-578. https://doi.org/10.1016/S0140-6736(08)60269-X

32. Ribeiro, R., Monteiro, C., Cunha, V., Oliveira, M.J., Freitas, M., Fraga, A., Príncipe, P., Lobato, C., Lobo, F., Morais, A., Silva, V., Sanches-Magalhães, J., Oliveira, J., Pina, F., Mota-Pinto, A., Lopes, C., \& Medeiros, R. 2012. Human periprostatic adipose tissue promotes prostate cancer aggressiveness in vitro. Journal of Experimental \& Clinical Cancer Research, 31(1): 1-11.

33. Sherman, B., Hernandez, A.M., Alhado, M., Menge, L. \& Price, R.S. 2020. Silibinin Differentially Decreases the Aggressive Cancer Phenotype in an In Vitro Model of Obesity and Prostate Cancer. Nutrition and Cancer, 72(2): 333-342. https://doi.org/10.1080/01635581.2019.1633363

34. Su, F., Ahn, S., Saha, A., DiGiovanni, J. \& Kolonin, M.G. 2019. Adipose stromal cell targeting suppresses prostate cancer epithelial-mesenchymal transition and chemoresistance. Oncogene, 38(11): 1979-1988. https://doi.org/10.1038/s41388-018-0558-8

35. Toren, P., Mora, B.C. \& Venkateswaran, V. 2013. Diet, obesity, and cancer progression: are adipocytes the link? Lipid Insights, 6: 37-45. https://doi.org/10.4137/LPI.S10871

36. Tumminia, A., Vinciguerra, F., Parisi, M., Graziano, M., Sciacca, L., Baratta, R. \& Frittitta, L. 2019. Adipose tissue, obesity and adiponectin: role in endocrine cancer risk. International Journal of Molecular Sciences, 20(12): 2863.

37. UICC. GLOBOCAN 2020: New Global Cancer Data. Available online: https://www.uicc.org/news/globocan2020-new-global-cancer-data

38. Wallerand, H., Robert, G., Pasticier, G., Ravaud, A., Ballanger, P., Reiter, R.E. \& Ferrière, J.-M. 2010. The epithelial-mesenchymal transition-inducing factor TWIST is an attractive target in advanced and/or metastatic bladder and prostate cancers. Urologic Oncology: Seminars and Original Investigations, 28(5): 473-479. https://doi.org/https://doi.org/10.1016/j.urolonc.2008.12.018

39. Zalesin, K.C., Franklin, B.A., Miller, W.M., Peterson, E.D. \& McCullough, P.A. 2008. Impact of obesity on cardiovascular disease. Endocrinology and Metabolism Clinics of North America, 37(3): 663-684.

40. Zhang, Z. \& Scherer, P.E. 2018. The dysfunctional adipocyte -a cancer cell's best friend. Nature Reviews Endocrinology, 14(3): 132-134. https://doi.org/10.1038/nrendo.2017.174 